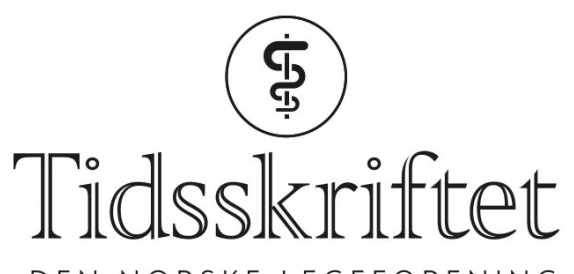

DEN NORSKE LEGEFORENING

\title{
Omikron? Hvorfor ikke epsilon?
}

SPRÅKSPALTEN

PETTER GJERSVIK

petter.gjersvik@tidsskriftet.no

Petter Gjersvik er medisinsk redaktør i Tidsskriftet og professor ved Institutt for klinisk medisin, Universitetet i Oslo.

Preben Aavitsland er overlege ved Folkehelseinstituttet og professor ved Pandemisenteret, Universitetet i Bergen.

Hvor mange bokstaver i det greske alfabetet har Verdens helseorganisasjon hoppet over ved klassifiseringen av SARSCoV-2-variantene? 


\section{$\mathrm{A} \alpha$ \\ B $\beta$ \\ $\Gamma \gamma$ \\ $\Delta \delta$ \\ $\mathrm{E} \varepsilon$ \\ $Z \zeta$ \\ $\mathrm{H} \eta$ \\ $\Theta \theta$ \\ I $\iota$

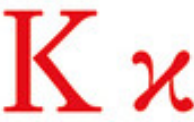 \\ $\Lambda \lambda$ \\ $\mathrm{M} \mu$ \\ $\mathrm{N \nu}$ \\ $\Xi \xi$ \\ Oo \\ $\Pi \pi$ \\ $\mathrm{P} \rho$ \\ $\sum \sigma \varsigma$ \\ 77 \\ Yv \\ $\Phi \varphi$

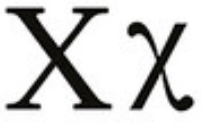 \\ $\Psi \psi$ \\ $\Omega \omega$}

Illustrasjon: Ihor Kashurin / iStock. Tilpasset av Tidsskriftet.

I løpet av koronapandemien har det oppstått mange varianter av SARS-CoV-2-viruset, som forårsaker covid-19 (1). Blant forskerne ble de første variantene omtalt med kompliserte kombinasjoner av bokstaver og tall, slik som B.1.1.7 og B.1.167.1, mens media gjerne betegnet dem i henhold til landet de først ble påvist i. I slutten av mai 2021 besluttet Verdens helseorganisasjon (WHO) å betegne de ulike virusvariantene etter bokstaver i det greske

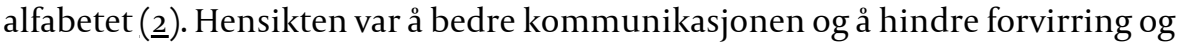
stigmatisering. Særlig oppmerksomhet har den såkalte deltavarianten fått, fordi den smitter lettere og gir mer alvorlig sykdom enn de andre variantene.

Nettopp da pandemien syntes å være på vei tilbake, dukket det i november 2021 opp nok en variant av SARS-CoV-2-viruset, denne gangen i Sør-Afrika. Denne varianten syntes å være enda mer smittsom enn deltavarianten. Verdens helseorganisasjon var raskt på banen, både med nye advarsler og med en egen betegnelse. Den nye virusvarianten fikk betegnelsen omicron (3), på norsk omikron (4).

\section{Det greske alfabetet}

Mange vil huske at de fem første bokstavene i det greske alfabetet kan skrives som alfa, beta, gamma, delta og epsilon (4). Bokstaven omikron er den 15. bokstaven i rekken. Hvorfor fikk den nye varianten av SARS-CoV-2-viruset betegnelsen omikron og ikke epsilon?

«Nye SARS-CoV-2-varianter har fått betegnelser fra det greske alfabetet $i$ den rekkefølgen de er blitt meldt inn» 
Verdens helseorganisasjon får fortløpende meldinger om nye SARS-CoV-2-varianter og vurderer hvorvidt de utgjør en ekstra helsetrussel. Disse har fått betegnelser fra det greske alfabetet i den rekkefølgen de er blitt meldt inn. Verdens helseorganisasjon opererer med to særskilte klasser virusvarianter: variant som gir bekymring (på engelsk Variant of Concern, VOC) og variant av interesse (Variant of Interest, VOI). I skrivende stund (7.12.2021) er det ifølge Verdens helseorganisasjons nettsider registrert fem varianter som gir grunn for bekymring: alfa-, beta-, gamma-, delta- og omikronvariantene (5). To varianter, lambda og my, er klassifisert som varianter av interesse.

Centers for Disease Control and Prevention (CDC) i USA opererer derimot med fire klasser, der kun delta og omikron er klassifisert som varianter som gir bekymring (므). De øvrige variantene er klassifisert som variant som monitoreres (Variant Being Monitored, VBM). Blant disse er epsilon betegnelsen på variantene B.1.427 og B.1.429.

Men Verdens helseorganisasjon og Centers for Disease Control and Prevention har likevel ikke helt holdt seg til rekkefølgen i det greske alfabetet: Man har valgt å hoppe over nr. 13 og 14, nemlig bokstavene nu/ny og xi/ksi (7.). Begrunnelsen var at nu/ny lett kan forveksles med ordet new på engelsk, og at Xi er et vanlig brukt kinesisk slektsnavn. Man forsøker dessuten å unngå betegnelser som kan krenke visse kulturer, nasjoner eller etniske grupper, ble det sagt (7.). Kinas president heter som kjent Xi Jinping.

\section{LITTERATUR}

1. Spurkland A. Når blir mutant til variant? Tidsskr Nor Legeforen 2021; 141. doi: 10.4045/tidsskr.21.0492. [CrossRef]

2. World Health Organization. WHO announces simple, easy-to-say labels for SARS-CoV-2 Variants of Interest and Concern. https://www.who.int/news/item/31-05-2021-who-announces-simple-easy-to-saylabels-for-sars-cov-2-variants-of-interest-and-concern Lest 6.12.2021.

3. World Health Organization. Classification of Omicron (B.1.1.529): SARS-CoV-2 Variant of Concern. https://www.who.int/news-room/statements/26-11-2021-classification-of-omicron-(b.1.1.529)-sars-cov-2variant-of-concern Lest 6.12.2021.

4. Store norske leksikon. Gresk alfabet. https://snl.no/gresk_alfabet Lest 6.12.2021.

5. World Health Organization. Tracking SARS-CoV-2 variants. https://www.who.int/en/activities/tracking-SARS-CoV-2-variants/ Lest 6.12.2021.

6. Centers for Disease Control and Prevention. SARS-CoV-2 Variant Classifications and Definitions. https://www.cdc.gov/coronavirus/2019-ncov/variants/variant-info.html Lest 6.12.2021.

7. Patel V. How Omicron, the new Covid-19 variant, got its name. New York Times 27.11.2021. https://www.nytimes.com/2021/11/27/world/africa/omicron-covid-greek-alphabet.html Lest 6.12.2021.

Publisert: 16. desember 2021. Tidsskr Nor Legeforen. DOI: 10.4045/tidsskr.21.0863

(C) Tidsskrift for Den norske legeforening 2023. Lastet ned fra tidsskriftet.no 26. april 2023. 